\title{
MATHEdunesa
}

Jurnal Ilmiah Pendidikan Matematika Volume 9 No. 1 Tahun 2020

ISSN :2301-9085

\section{PROSES BERPIKIR KREATIF PESERTA DIDIK DALAM MEMECAHKAN MASALAH SOAL PISA DITINJAU DARI GAYA BELAJAR GLOBAL-ANALITIK}

\author{
Nailis Saida \\ Pendidikan Matematika, FMIPA, Universitas Negeri Surabaya, e-mail: nailissaida@mhs.unesa.ac.id \\ Ismail \\ Pendidikan Matematika, FMIPA, Universitas Negeri Surabaya, e-mail: ismail@unesa.ac.id
}

\begin{abstract}
Abstrak
Proses berpikir kreatif adalah suatu tahapan yang digunakan seseorang untuk menghasilkan ide baru dan alternatif cara/jawaban meliputi tahapan persiapan, inkubasi, iluminasi dan verifikasi. Masalah yang digunakan untuk melihat proses berpikir kreatif seseorang yaitu soal PISA. Terdapat beberapa faktor yang memengaruhi proses berpikir kreatif seseorang salah satunya adalah adanya perbedaan gaya belajar. Gaya belajar yang digunakan adalah gaya belajar global dan analitik. Tujuan penelitian ini mendeskripsikan proses berpikir kreatif peserta didik dalam memecahkan masalah soal PISA dengan gaya belajar global dan analitik. Penelitian ini menggunakan penelitian deskriptif dengan pendekatan kualitatif. Subjek penelitian di kelas X-IPA 1 SMA Negeri 8 Kediri terdiri dari satu orang bergaya belajar global dan satu orang bergaya belajar analitik. Hasil penelitian ini menunjukkan bahwa proses berpikir kreatif peserta didik dalam memecahkan masalah soal PISA dengan gaya belajar global melalui tahap persiapan, inkubasi, iluminasi dan verifikasi. Peserta didik mengerjakan soal PISA dengan dua cara berbeda namun hasil pengerjaan tidak secara runtut, menuliskan hasil akhir saja. Tahap inkubasi, peserta didik mengalami kejenuhan dan kesulitan mengerjakan pada salah satu cara akibatnya berdiam diri sejenak. Selanjutnya, proses berpikir kreatif peserta didik dalam memecahkan masalah soal PISA dengan gaya belajar analitik juga melalui tahap persiapan, inkubasi, iluminasi dan verifikasi. Peserta didik mengerjakan soal PISA dengan dua cara berbeda, hasil pengerjaan dituliskan secara runtut, langkah demi langkah jelas, rinci. Tahap inkubasi, peserta didik tidak mengalami kesulitan.
\end{abstract}

Kata Kunci: proses berpikir kreatif, soal PISA, gaya belajar.

\begin{abstract}
The process of creative thinking is a step that someone uses in produce new ideas and alternative ways/answers include the preparation, incubation, illumination and verification. The problem used to describe process of creative thinking is PISA problems. There are many factors to influence process of creative thinking one of them is difference learning style. The purpose of this research to describe students' creative thinking processes in PISA roblem solving with global and analytic learning style. This research uses descriptive research with a qualitative approach. The research subjects were taken by two students each in global and analytic learning style in class X-IPA 1 of Senior High School 8 Kediri. The result of this research showed that students' creative thinking processess in PISA problem solving in PISA with global learning style can through preparation, incubation, illumination and verification. The student can do PISA problem in two different ways but the result are not coherent, do not write the basic formula and some write the final answer. In the incubation stage, student was saturation and difficulty on one of the ways which is found and the effect do silence for a moment. The next, student' creative thinking processes in PISA problem solving with analytic learning style can also through preparation, incubation, illumination and verification. The student can do PISA problem in two different ways, the result are written coherently, step by step written clearly. In the incubation stage, student not have problem.
\end{abstract}

Keywords: creative thinking process, PISA, learning style. 


\section{PENDAHULUAN}

Pendidikan di Indonesia selalu mengalami perubahan seiiring perkembangan zaman di era globalisasi. Perkembangan zaman juga diikuti oleh berkembangnya IPTEK saat ini. Semakin berkembangnya IPTEK, semakin banyak tuntutan seseorang untuk menghadapi tantangan di berbagai bidang. Salah satunya bidang ilmu pengetahuan pada matematika. Matematika diperlukan untuk semua kalangan dalam kehidupan sehari-hari. Tidak hanya itu, matematika memerlukan polaberpikir untuk menyelesaikan masalah salah satunya pada berpikir kreatif.

Permendikbud (2013) menyatakan bahwa salah satu tujuan dari kurikulum 2013 adalah agar seseorang memiliki kemampuan hidup sebagai pribadi yang kreatif. Hal ini menandakan bahwa pola berpikir kreatif seseorang perlu diasah dan penting di dalam dunia pendidikan saat ini.

Berpikir kreatif merupakan salah satu dari berpikir tingkat tinggi. Erdogan, dkk (2009) menyatakan bahwa berpikir kreatif memungkinkan seseorang dalam menghasilkan produk baru, menemukan solusi baru dan mencapai sintesis. Berpikir kreatif juga memerlukan imajinasi seseorang agar dapat mencari ide, cara yang baru sehingga dapat mencari ide, cara yang baru untuk memecahkan masalah yang diberikan.

Birgili (2015) berpendapat bahwa berpikir kreatif berhubungan dengan berpikir kritis dan pemecahan masalah. Hal ini menandakan bahwa berpikir kreatif diperlukan untuk memecahkan suatu masalah dengan menentukan ide-ide dan cara baru sehingga mendapatkan soluri yang baru pula. Dalam memecahkan suatu masalah tidak hanya memikirkan hasil akhir namun memerlukan proses dalam memecahkan masalah agar mengetahui langkah demi langkahnya.

Berpikir kreatif tidak hanya dipandang dari sisi produknya saja melainkan dapat dipandang dari sisi prosesnya. Hal ini seperti pendapat Huriyah (2017) menyatakan bahwa berpikir kreatif melibatkan prosesnya dinamakan proses berpikir kreatif. Proses berpikir kreatif merupakan salah satu tahapan yang digunakan untuk mendeskripsikan berpikir kreatif seseorang. Wallas menyatakan bahwa proses berpikir kreatif terdapat empat tahapan yang meliputi tahapan persiapan, inkubasi, iluminasi dan verifikasi (Munandar, 2014).

Salah satu masalah yang dapat digunakan untuk berpikir tingkat tinggi (berpikir kreatif) pada soal PISA. PISA adalah suatu program internasional yang bertujuan untuk menilai keterampilan dan kemampuan peserta didik pada usia 15 tahun (OECD, 2018). Berdasarkan data Organisation for Economic Co-oeration and Development (OECD) tahun 2015, skor rata-rata kemampuan matematika peserta didik untuk negara Indonesia mencapai skor 386 dan skor tersebut masih jauh dibandingkan dengan negara lain (OECD, 2018). Hal ini dapat dikatakan bahwa kemampuan peserta didik dalam PISA masih rendah. Konten PISA yang digunakan untuk berpikir kreatif pada konten space and shape karena konten ini dapat diselesaikan dengan berbagai macam cara dan menggabungkan dari beberapa bangun datar sehingga diperoleh suatu jawaban atau solusinya.

Salah satu keterkaitan berpikir kreatif dengan adanya gaya belajar. Eishani, dkk (2014) berpendapat bahwa meski penemuan individu berbeda, belajar dan kreativitas terkait gaya belajar dapat menjadikan faktor penting pada pertumbuhan dan kepuasan perkembangan pendidikan. Oleh karena itu, gaya belajar terkait dengan kreativitas karena kreativitas merupakan hasil dari proses berpikir kreatif dan dapat diterapkan pada perkembangan pendidikan saat ini.

Gaya belajar adalah suatu cara yang dimiliki oleh seseorang dalam menyerap, memeroleh informasi untuk memecahkan suatu masalah secara maksimal. Gaya belajar model Witkin menurut Tobias terdapat dua gaya belajar diantaranya gaya belajar global dan analitik (Tobias, 2009). Seseorang yang termasuk gaya belajar global adalah seseorang yang memikirkan suatu masalah secara keselutuhan tanpa memikirkan hal-hal rinci dan mampu mengaitkan satu hal dengan lainnya (Tobias, 2009). Dalam hal ini, seseorang bergaya belajar global merasa kesulitan ketika menyelesaikan suatu masalah dengan hal-hal rinci. Ketika diberikan suatu permasalahan, orang bergaya belajar global dapat memandang masalah tersebut dengan berbagai arah tidak hanya memandang satu arah saja. Sebaliknya, seseorang yang termasuk gaya belajar analitik adalah seseorang yang memikirkan hal-hal rinci ketika diberikan suatu permasalahan (Tobias, 2009). Dalam hal ini, seseorang bergaya belajar analitik kurang menyukai sesuatu yang dipikirkan secara menyeluruh. Dari kedua gaya belajar tersebut dapat dilihat bahwa terdapat suatu perbedaan. Perbedaan ini dapat mempengaruhi proses berpikir kreatif seseorang.

Berdasarkan uraian tersebut maka peneliti melakukan penelitian dengan judul "Proses Berpikir Kreatif Peserta Didik dalam Memecahkan Masalah Soal PISA Ditinjau dari Gaya Belajar Global-Analitik".

Selain itu, tujuan penelitian ini untuk mendeskripsikan proses berpikir kreatif dalam memecahkan masalah soal PISA dengan gaya belajar global dan analitik.

\section{METODE}

Penelitian ini menggunakan penelitian deskriptif dengan pendekatan kualitatif yang bertujuan untuk mendeskripsikan proses berpikir kreatif peserta didik dalam memecahkan masalah soal PISA pada gaya belajar global dan analitik. Rancangan penelitian ini meliputi 
penyusunan instrumen, validasi instrumen dengan cara konsultasi kepada dosen pembimbing, pengambilan data, penentuan subjek penelitian, tes berpikir kreatif, wawancara, analisis data, penarikan kesimpulan dan penyusunan laporan penelitian. Instrumen yang digunakan berupa tes berpikir kreatif dengan menggunakan adaptasi soal PISA tahun 2012 dan pedoman wawancara.

Penelitian ini dilakukan pada semester gasal di kelas X-IPA 1 Sekolah Menengah Atas Negeri 8 Kediri. Pada tanggal 8 Agustus 2019 diperoleh data angket penggolongan gaya belajar peserta didik dan tes kemampuan matematika. Selanjutnya, pada tanggal 11 Agustus 2019 diperoleh data tes berpikir kreatif sekaligus wawancara dengan subjek penelitian. Subjek penelitian dipilih dua peserta didik dengan masing-masing gaya belajar yang berbeda.

Teknik pengumpulan data menggunakan metode angket, tes dan wawancara. Angket yang digunakan berasal dari adopsi angket gaya belajar pada buku Cara Mereka Belajar (The Way They Learn) berisi 15 pernyataan dengan dua opsi jawaban dan dipilih peserta didik sesuai dengan kondisi dirinya. Setelah itu dianalisis dengan cara menghitung jawaban terbanyak dari kedua opsi tersebut. Jika jumlah jawaban terbanyak pada opsi A maka peserta didik tergolong gaya belajar analitik. Sebaliknya, jika jumlah jawaban terbanyak pada opsi B maka peserta didik tergolong gaya belajar global.

Metode tes yang digunakan dalam penelitian ini yaitu tes berpikir kreatif. Soal yang digunakan merupakan adaptasi dari soal PISA tahun 2012 pada konten space and shape. Soal diberikan kepada dua subjek penelitian yang dipilih dengan kemampuan matematika tinggi dan jenis kelamin disamakan. Tes ini diberikan untuk mendeskripsikan proses berpikir kreatif dalam memecahkan masalah soal PISA dan dianalisis sesuai dengan indikator proses berpikir kreatif yang sudah dibuat.

Wawancara dilakukan peneliti untuk menanyakan hal-hal yang tidak ada pada hasil pengerjaan tes berpikir kreatif dan memperjelas data tentang proses berpikir kreatif subjek penelitian. Setelah diperoleh data wawancara selanjutnya data dianalisis melalui tahap reduksi data, penyajian data dan penarikan kesimpulan.

\section{HASIL DAN PEMBAHASAN}

Angket gaya belajar diisi oleh 35 peserta didik di kelas XIPA 1 SMA Negeri 8 Kediri yang diperoleh peserta didik bergaya belajar global sebanyak 12 orang dan analitik sebanyak 23 orang. Dari hasil tersebut dipilih dua peserta didik dengan jenis kelamin sama dan gaya belajar berbeda.

Selanjutnya, hasil tes kemampuan matematika di kelas X-IPA 1 terdiri dari peserta didik yang termasuk kategori kemampuan matematika tinggi sebanyak 9 orang, sedang sebanyak 15 orang dan rendah sebanyak 11 orang.
Dari hasil tersebut dipilih kategori kemampuan matematika tinggi dan jenis kelamin sama.

Hasil proses berpikir kreatif peserta didik dalam memecahkan masalah soal PISA dengan gaya belajar global melalui empat tahapan Wallas meliputi tahapan persiapan, inkubasi, iluminasi dan verifikasi. Pada tahap persiapan, peserta didik bergaya belajar global dapat mengidentifikasi masalah dengan cara membaca soal, memahaminya, menemukan kata kunci dari soal PISA yang diberikan yaitu menentukan luas lantai rumah. Selain itu, peserta didik dapatmengumpulkan informasi pada soal dan mengaitkan informasi yang ada pada soal dengan informasi yang dimiliki menggunakan materi luas bangun datar. Keterkaitan ini dapat digunakan untuk menentukan konsep yang cocok dalam memecahkan masalah soal PISA. Hal ini sesuai dengan Mustangin \& Debora (2009) yang menyatakan bahwa orang yang berpikir secara global dapat melihat hubungan antar satu bagian dengan bagian lainnya. Selanjutnya, peserta didik bergaya global mencari ide penyelesaian yang cocok dan dapat menentukan dua cara yang berbeda namun ini masih dalam angan-angan saja. Ide penyelesaian yang ditemukan untuk menentukan luas lantai pertama mengitung luas tiap bagian dengan rumus luas persegi panjang dan kedua menentukan luas yang besar dikurangi dengan luas yang kecil. Hal ini, peserta didik memikirkan terlebih dahulu ide yang digunakan. Proses ini menunjukkan bahwa peserta didik melalui tahap persiapan. Hal ini sesuai dengan Wallas (dalam Munandar, 2014) bahwa pada tahap persiapan, seseorang dapat mengidentifikasi masalah dan menentukan informasi dari masalah tersebut.

Tahap inkubasi merupakan tahap kedua dari proses berpikir kreatif Wallas. Peserta didik merasa kesulitan untuk memecahkan masalah dari salah satu cara yang ditemukan yaitu menentukan luas lantai dengan menghitung luas dari setiap bagiannya dan berdiam diri sejenak. Hal ini sesuai dengan Tobias (2009) menjelaskan bahwa orang global merasa sulit untuk memecahkan seluruh gambaran menjadi beberapa bagian. Selain itu, peserta didik merasa kejenuhan akibatnya melakukan kegiatan lain yang tidak ada kaitannya dengan soal. Proses tersebut sesuai dengan Wallas (dalam Munandar, 2014) menyatakan bahwa tahap inkubasi dilakukan seseorang untuk berhenti sejenak dan tidak memikirkan soal tersebut.

Tahap iluminasi merupakan tahap ketiga dari proses berpikir kreatif Wallas. Peserta didik memunculkan ide setelah melakukan berdiam diri sejenak dan memunculkan titik terang. Tidak hanya itu, peserta didik dapat mengingat kembali strategi yang digunakan dalam memecahkan masalah soal PISA. Proses tersebut sesuai dengan Deporter \& Hernacki (2015) berpendapat bahwa tahap iluminasi dilakukan seseorang untuk memunculkan gagasan ke dalam pikirannya. 
Tahap verifikasi merupakan tahap terakhir dari proses berpikir kreatif Wallas. Peserta didik melaksanakan perhitungan dari dua strategi yang sudah dianggap cocok namun dalam proses pengerjaan tidak menuliskan rumus yang digunakan dan menuliskannya secara umum saja seperti gambar berikut ini.

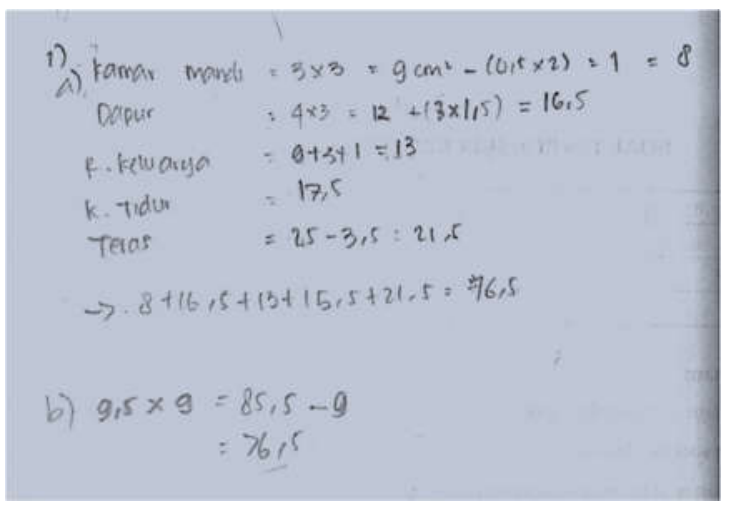

Gambar 1. Hasil Pengerjaan Subjek PG

Proses pengerjaan tidak rinci bahkan ada pula menuliskan hasil akhirnya saja. Dalam hal ini, perhitungan tersebut hanya di dalam pikirannya saja. Peserta didik melakukan pengecekan langkah-langkah beserta hasil akhirnya dan yakin dengan hasil akhirnya. Proses tersebut dapat dilalui pada tahap verifikasi yang sesuai dengan Wallas (dalam Munandar, 2014) menyatakan bahwa tahap verifikasi merupakan tahap evaluasi di mana ide atau gagasan diuji.Ketika peserta didik melakukan kesulitan dalam proses pengerjaan dari salah satu cara yang ditemukan, peserta didik melewatinya dan melanjutkan dengan pekerjaan lainnya. Hal ini sesuai dengan Tobias (2009) menyatakan bahwa salah satu kelebihan orang global dapat mengerjakan beberapa hal dalam satu waktu.

Selanjutnya, proses berpikir kreatif dalam memecahkan masalah soal PISA dengan gaya belajar analitik juga melalui empat tahapan Wallas meliputi tahap persiapan, inkubasi, iluminasi dan verifikasi. Pada tahap persiapan, peserta didik bergaya belajar analitik dapat mengidentifikasi masalah dengan cara membaca soal, memahaminya, menemukan kata kunci dari soal PISA yang diberikan, mengumpulkan informasi pada soal dan mengaitkan informasi yang ada pada soal dengan informasi yang dimiliki menggunakan materi skala dan luas bangun datar seperti persegi panjang. Keterkaitan ini dapat digunakan untuk menentukan konsep yang cocok dalam memecahkan masalah soal PISA. Selanjutnya, peserta didik bergaya analitik mencari ide penyelesaian yang cocok dan dapat menentukan dua cara yang berbeda namun ini masih dalam angan-angan saja. Pertama, menghitung panjang tiap sisi terlebih dahulu, tarik garis bantu dan terbentuklah persegi panjang baru. Lalu luas lantai dapat dihitung dari luas keseluruhan dikurangi luas persegi panjang baru. Kedua, luas lantai diperoleh dari menghitung semua luas ruangan satu-satu lalu hasilnya dijumlahkan.Hal ini, peserta didik memikirkan terlebih dahulu ide yang digunakan. Proses ini menunjukkan bahwa peserta didik melalui tahap persiapan. Hal ini sesuai dengan Wallas (dalam Munandar, 2014) bahwa pada tahap persiapan, seseorang dapat mengidentifikasi masalah dan menentukan informasi dari masalah tersebut.

Tahap inkubasi merupakan tahap kedua dari proses berpikir kreatif Wallas. Peserta didik bergaya belajar analitik tidak merasa kesulitan untuk memecahkan masalah sehingga tidak berdiam diri sejenak untuk memikirkan soal yang diberikan. Walaupun tidak merasa kesulitan, peserta didik merasa kejenuhan ketika mengerjakan soal akibatnya peserta didik memikirkan tugas sekolah yang diberikan guru. Ini menandakan bahwa peserta didik bergaya belajar analitik telah melakukan hal lain yang tidak ada kaitannya dengan soal PISA. Proses tersebut sesuai dengan Wallas (dalam Munandar, 2014) menyatakan bahwa tahap inkubasi dilakukan seseorang berhenti sejenak untuk tidak memikirkan masalahnya dan ia melakukan kegiatan lain.

Tahap iluminasi merupakan tahap ketiga dari proses berpikir kreatif Wallas. Peserta didik bergaya belajar analitik dapat menemukan ide dan strategi untuk memecahkan masalah setelah kembali fokus. Proses tersebut dilalui peserta didik bergaya belajar analitik dengan menandakan timbullnya titik terang atau titik fokus. Hal ini sesuai dengan Wallas (dalam Munandar, 2014) berpendapat bahwa tahap iluminasi ini dikatakan sebagai timbulnya "insight" atau "Aha-Erlebnis".

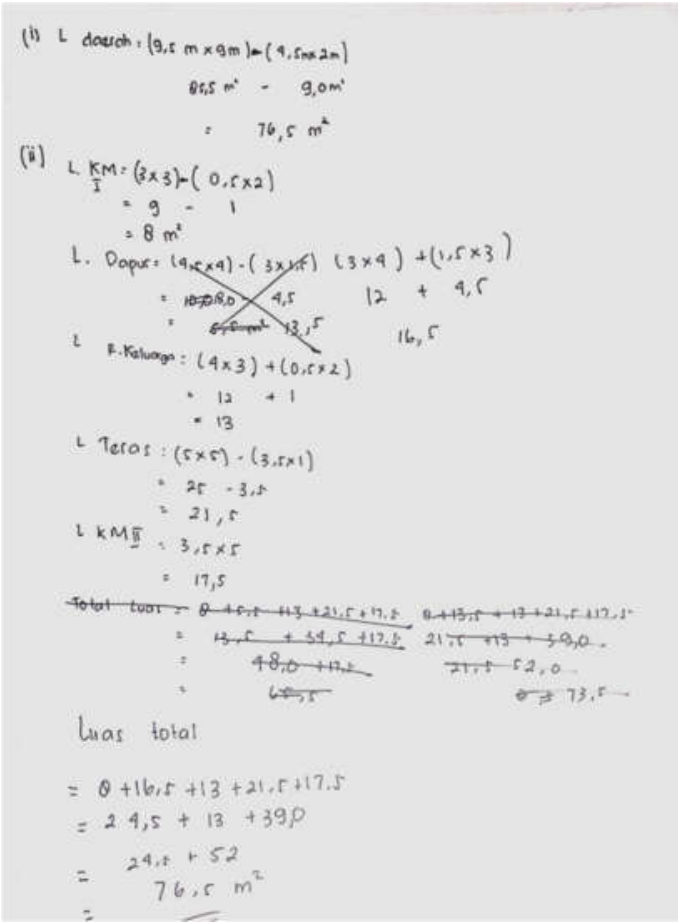

Gambar 2. Hasil Pengerjaan Subjek PA 
Tahap verifikasi merupakan tahap terakhir dari proses berpikir kreatif Wallas. Peserta didik melaksanakan perhitungan dari dua ide yang sudah ditemukan untuk menghasilkan cara/strategi penyelesaian yang berbedaa seperti gambar berikut ini. Proses perhitungan dengan bantuan operasi penjumlahan, pengurangan dan perkalian. Ketika peserta didik bergaya belajar analitik melaksanakan perhitungan dari dua cara yang sudah dianggap cocok, peserta didik menuliskan cara hingga menemukan hasil akhir secara rinci, detail dan runtut walaupun tidak menuliskan rumus dasarnya. Hal ini sesuai dengan Tobias (2009) menyatakan bahwa kelebihan dari seseorang analitis yaitu dapat memperhatikan hal-hal secara detail dan lebih berfokus pada hal-hal yang rinci.

Setelah melakukan perhitungan, peserta didik bergaya belajar analitik melakukan proses pengecekan ulang terhadap langkah-langkah yang sudah dituliskan. Hal ini dilakukan bahwa menurutnya ada suatu kesalahan dalam proses perhitungan. Ketika pengecekan ulang terhadap langkah-langkah penyelesaian tentunya sekaligus pengecekan terhadap hasil akhir yang diperoleh dan peserta didik yakin dengan hasil akhir walaupun tidak menuliskan kesimpulan. Proses ini dilakukan peserta didik melalui tahap verifikasi. Hal ini sesuai dengan Wallas (dalam Munandar, 2014) menyatakan bahwa tahap verifikasi adalah tahap evaluasi di mana ide atau gagasan diuji. Tahap ini melibatkan proses perhitungan dan menghasilkan kreasi peserta didik.

\section{PENUTUP}

\section{Simpulan}

Berdasarkan hasil penelitian dan pembahasan di atas maka dapat diuraikan kesimpulan sebagai berikut.

1. Proses Berpikir Kreatif Peserta Didik dalam Memecahkan Masalah Soal PISA dengan Gaya Belajar Global

Tahap persiapan, peserta didik bergaya belajar global mengidentifikasi masalah dengan cara membaca soal, memahami dan menemukan kata kunci. Peserta didik mengumpulkan informasi pada soal digunakan untuk mengaitkan dengan informasi yang dimiliki. Peserta didik menemukan konsep sehingga dapat mencari ide dan strategi penyelesaian masalah.

Tahap inkubasi, peserta didik melakukan kegiatan yang tidak ada kaitannya dengan soal PISA, merasa jenuh dan kesulitan dari salah satu ide/cara yang ditemukan.

Tahap iluminasi, peserta didik menemukan titik terang dan memunculkan ide/strategi penyelesaian setelah berdiam diri sejenak.

Tahap verifikasi, peserta didik melaksanakan perhitungan dari dua strategi yang ditemukan dan dianggap cocok. Peserta didik menuliskan cara tidak runtut, ada yang disajikan jawaban akhir saja. Peserta didik melaksanakan pengecekan langkah-langkah penyelesaian dan hasil akhir serta yakin terhadap hasil pengerjaannya.

2. Proses Berpikir Kreatif Peserta Didik dalam Memecahkan Masalah Soal PISA dengan Gaya Belajar Analitik

Tahap persiapan, peserta didik bergaya belajar global mengidentifikasi masalah dengan cara membaca soal, memahami dan menemukan kata kunci. Peserta didik mengumpulkan informasi pada soal digunakan untuk mengaitkan dengan informasi yang dimiliki. Peserta didik menemukan konsep sehingga dapat mencari ide dan strategi penyelesaian masalah.

Tahap inkubasi, peserta didik memikirkan sesuatu yang tidak ada kaitannya dengan soal PISA. Peserta didik merasa jenuh dan namun tidak merasa kesulitan dalam memecahkan soal PISA.

Tahap iluminasi, peserta didik tetap menemukan ide/strategi penyelesaian yang digunakan setelah kembali fokus dari rasa kejenuhan.

Tahap verifikasi, peserta didik melaksanakan perhitungan dari dua strategi yang ditemukan dan dianggap cocok. Peserta didik menuliskan cara runtut dan detail. Peserta didik melaksanakan pengecekan langkah-langkah penyelesaian dan hasil akhir serta yakin terhadap hasil pengerjaannya.

\section{Saran}

Berdasarkan hasil penelitian dan kesimpulan yang diperoleh maka peneliti memberikan saran kepada peneliti selanjutnya sebagai berikut.

1. Pemilihan soal PISA pada penelitian ini hanya menghasilkan beberapa alternatif cara penyelesaian saja dan jawaban akhir tunggal. Untuk itu, peneliti menyarankan kepada peneliti selanjunya agar memilih soal PISA yang dapat menghasilkan beberapa alternatif cara penyelesaian dan berbagai variasi jawaban benar.

2. Subjek penelitian ini dipilih berdasarkan hasil angket gaya belajar global dan analitik. Jumlah skor pada angket gaya belajar keduanya hampir sama sehingga hasil pengerjaan soal PISA juga hampir sama. Agar dapat dilihat perbedaan yang menonjol dari kedua gaya belajar tersebut maka peneliti menyarankan kepada peneliti selanjutnya untuk memilih subjek penelitian dengan skor pada angket gaya belajar yang jauh berbeda sehingga dapat dilihat perbedaan hasil pengerjaannya. 


\section{DAFTAR PUSTAKA}

Birgili, Bengi. 2015. "Creative and Critical Thinking Skills in Problem-base Learning Environments". Journal of Gifted Education and Creativity. Vol.2 (2):pp.72.

Deporter, Bobbi \& Hernacki, Mike. 2015. Quantum Learning: Membiasakan Belajar Nyaman dan Menyenangkan. Terjemahan Alwiyah Abdurrahman. Bandung: Penerbit Kaifa.

Eishani, Khalil Allah, dkk. 2014. "The Relationship Between Learning Styles and Creativity". Procedia Social and Behavioral Sciences:pp.55.

Erdogan, dkk. 2009. "The Effect of The Van Hiele Model Based Instruction on the Creative Thinking Levels og $6^{\text {th }}$ Grade Primary School Student". Educational Sciences: Theory \& Practice. Vol.9 (1):pp. 185.

Huriyah, Nadilah M. "Proses Berpikir Kreatif Siswa SMA dalam Memecahkan Masalah Matematika Open-ended ditinjau dari Kemampuan Matematika”. Jurnal Ilmiah Pendidikan Matematika. Vol.2 (6): hal.50.

Munandar, Utami. 2014. Pengembangan Kreativitas Anak Berbakat. Jakarta: Rineka Cipta.

Mustangin \& Debora, Agustin. 2009. "Penerapan Global Learning dan Mind Mapping dalam Pembelajaran Matematika sebagai Jaringan Konsep". Prosiding dalam Seminar Nasional Matematika dan Pendidikan Matematika, 5 Desember 2009.

OECD. 2018. PISA 2015 Result in Fokus. Paris: OECD Publishing.

Permendikbud. 2013. Salinan Lampiran Peraturan Menteri Pendidikan dan Kebudayaan Nomor 69 Tahun 2013 tentang Kerangka Dasar dan Struktur Kurikulum Sekolah Menengah Atas/Madrasah Aliyah. Jakarta: Permendikbud.

Tobias, Cynthia Ulrich. 2009. Cara Mereka Belajar (The Way They Learn). Terjemahan Fokus pada Keluarga Indonesia. Jakarta: Pionir Jaya. 